\title{
Adjustment of the expedite method for clay content determination in Rondônia soils
}

\author{
Ajuste de método expedito para determinação de teor de argila em solos de Rondônia
}

\author{
Jairo André Schlindwein ${ }^{\mathrm{F}}$ Alan Antonio Miotti ${ }^{\mathrm{II}}$ Elaine Cosma Fioreli-Perira ${ }^{\mathrm{I}}$ \\ Petrus Luiz de Luna Pequeno ${ }^{\mathrm{I}}$ Leandro Bortolon ${ }^{\mathrm{III}}$ \\ Alaerto Luiz Marcolan ${ }^{\mathrm{IV}}$
}

\section{- NOTE -}

\begin{abstract}
Soil clay content is an important soil attribute and has been used to classification of phosphorus status in the soil in order to determinate the needing of phosphorus amounts to be applied to crops production. The aim of this research was to adjust the method for soil clay content determination, adopted by the laboratories of Southern Brazil (ROLAS-RS/SC), for soil clay content evaluation in Rondônia soils. The study was conducted using 50 soil samples from Rondônia State with wide range clay content. It was tested shaking periods (1.5, 2.0 and $2.5 \mathrm{~h}$ ) associated with periods for soil particles decantation (1.5 and 2.0h) to correlate with the standard method for soil texture testing, known as the pipette method. Clay content determined through this method was significantly correlated with pipette method. The better treatment was the combination of $2.0 \mathrm{~h}$ of shaking and $1.5 \mathrm{~h}$ of decantation, resulted in total period of 3.5h, which reduced the period to determine the soil clay content without loss of accuracy.
\end{abstract}

Key words: clay determination, clay decantation, shaking period, soil texture, soil physics.

\section{RESUMO}

O teor de argila é um importante atributo de solo e é utilizado na determinação de faixas de teores de fósforo para fins de recomendação de adubação. O objetivo deste trabalho foi ajustar o método de determinação de argila utilizado pelos laboratórios da ROLAS-RS/SC para avaliar os teores de argila dos solos de Rondônia. O estudo foi conduzido com 50 amostras de solos do Estado de Rondônia, com diferentes teores de argila. $O$ teor de argila foi determinado utilizando-se o método da ROLAS-RS/SC, com diferentes períodos de agitação $(1,5 ; 2,0$ e 2,5h) e de decantação das partículas do solo $(1,5$ e 2,0h) e o método da pipeta, considerado padrão para essa determinação. Os teores de argila determinados nas combinações de períodos de agitação $e$ de decantação se correlacionaram significativamente com os teores determinados pelo método da pipeta. $O$ melhor tratamento foi a combinação de 2,0h de agitação e 1,5h de decantação, resultando em tempo total de 3,5h, que reduz o tempo para determinação do teor de argila do solo sem perda significativa da eficiência.

Palavras-chave: determinação de argila, decantação de argila, tempo de agitação, textura do solo, física do solo.

The soil clay is the soil fraction with diameter $<0.002 \mathrm{~mm}$, which determine important chemical and physical characteristics to soils with colloidal properties (HILLEL, 2003). The clay content in soil has been used for several applications that influence the tillage system adopted, soil water infiltration and water holding capacity, lime and fertilization application methods and rates and many others agronomic and environmental applications (REICHERT et al., 2009). Clay content in soil is well correlated with soil phosphorus (P) forms, affecting its availability and supply of $\mathrm{P}$ to plants. Thereby, soil clay content is being efficiently used to classify $\mathrm{P}$ status in soils prior to $\mathrm{P}$ recommendations to crops in Brazil, when the

'Universidade Federal de Rondônia (UNIR), Av. Norte Sul, 7300, 98789-000, Rolim de Moura, RO, Brasil. E-mail: jairojas@unir.br. *Autor para correspondência.

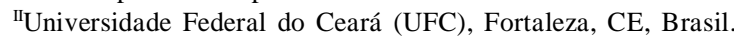

"IIEmbrapa Pesca e Aquicultura, Palmas, TO, Brasil.

${ }^{\mathrm{IV}}$ Embrapa Rondônia, Porto Velho, RO, Brasil. 
Mehlich-1 solution is used to soil P extraction (CFSRS/ $\mathrm{SC}, 2004)$. $\mathrm{P}$ is one the most limited nutrient for crop production in tropical soils, being usually necessary the application of high amounts to obtain reasonable yields (SANCHES; UEHARA, 1980). For Rondônia soils, there is a gap of information regarding the adequate method to determine the soil clay content that could be filled out to improve the $\mathrm{P}$ recommendation use in agriculture.

In clayey soils, the $\mathrm{P}$ displacement from solid phase to soil solution, and then until the roots surface, is more efficient than in sandy soils. This contrast, with lesser P extraction with Mehlich-1 solution in clayey soils, generates different soil P critical levels according to soil clay content (CFSEMG, 1999; SOUZA \& LOBATTO, 2002; CFSRS/SC, 2004; CUBILLA et al., 2007; SCHLINDWEIN \& GIANELLO, 2008). The determination of the soil $P$ availability classes using $\mathrm{P}$ values extracted with Mehlich-1 solution and the soil clay content with the standard method proposed by EMBRAPA (1997) is considered efficient. However, the method increases the labor, being cumbersome to day-to-day use in the routine of soil testing laboratory. Thereby, the aim of this research was to propose adjustment in the efficient and fast method for soil clay content determination adopted by the "Rede Oficial de Laboratórios de Análises de Solo" (ROLAS-RS/SC) in Southern Brazil to use in Rondônia soils prior to classification of soil $\mathrm{P}$ extracted by Mehlich-1 solution.

The study was conducted in the Soil Testing Laboratory of the Agronomy College from the Rondônia Federal University (UNIR). Fifty soil samples of the most representative soil classes (Latossolos, Argissolos, Nitossolos, Luvissolos, Cambissolos according to Brazilian classification) from Rondônia State, which are commonly used for agricultural production, were taken at $0-20 \mathrm{~cm}$ soil depth. The samples was separated in five classes of soil clay content (0-200, 200-300, 300-400, 400-500 and 500-800g $\mathrm{kg}^{-1}$ ), determined by the pipette method (EMBRAPA, 1997), with ten samples from in each soil clay content class. The soil organic matter determined by WalkleyBlack method ranged from 0.5 to $22.0 \mathrm{~g} \mathrm{~kg}^{-1}$, the soil available P (Mehlich-1 solution) ranged from 0.2 to
$13.3 \mathrm{mg} \mathrm{kg}^{-1}$, and the soil cation exchange capacity extracted with $\mathrm{KCl} 1 \mathrm{~mol} \mathrm{~L}^{-1}$ ranged from 4.2 to $7.8 \mathrm{cmol}_{\mathrm{c}} \mathrm{kg}^{-1}$.

The soil clay content determined with the pipette method (EMBRAPA, 1997) is considered standard to soil clay content determination. This method is laborious, slow and difficult to execute routinely in the soil laboratory for chemical analysis, although it is a very efficient method used to determine soil fertility and recommend nutrient. To compare this standard method, soil clay content was also determined with the method adopted by Rede Oficial de Laboratórios de Análises de Solo from Southern Brazil (ROLAS-RS/SC), described in Tedesco et al., 1995). It is a fast method, with efficient precision and easy execution in routine soil testing.

In the method adopted by ROLAS-RS/SC, the clay content is determined with a small densimeter inside a pip tube with $20 \mathrm{~mm}$ in diameter and $275 \mathrm{~mm}$ in high, after dispersion of $10 \mathrm{~g}$ of soil with $15 \mathrm{~mL}$ of $\mathrm{NaOH}$ $0.167 \mathrm{~mol} \mathrm{~L}^{-1}$, standing by 15 to 18 hours, shaking by $2.0 \mathrm{~h}$ and decantation by $2.5 \mathrm{~h}$. The value obtained was correlated with soil clay content determined by the pipette method described in EMBRAPA (1997).

The method described in TEDESCO et al. (1995) was modified and tested in shaking periods (S) of 1.5, 2.0 and $2.5 \mathrm{~h}$ with decantation period fixed in $2.5 \mathrm{~h}$, using an orbital shaker and a sphere-glass to improve the soil detachment, and decantation period (D) of 1.5 and $2.0 \mathrm{~h}$ after applying shaking period of 2.0h. The shake was carried out in flask with $70 \mathrm{~mm}$ of diameter and decantation in flask with $20 \mathrm{~mm}$ of diameter. The soil analysis was carry out in duplicates and the statistical analysis included the descriptive statistics, ANOVA and multiple average comparisons with Tukey test. The soil clay content estimated with the methods tested was used to the correlation analysis.

On average, the highest soil clay content was found when used the EMBRAPA (1997) method. The shaking and decantation periods showed differences among treatments in the fifty soils evaluated (Table 1). The treatment $2.0 \mathrm{~h}$ of $\mathrm{S}$ and $1.5 \mathrm{~h}$ of D showed the highest clay content values, followed by the treatment with $\mathrm{S}$ and D of, respectively, 2.0 and 2.5h, 2.5 and 2.5h, and 2.0 and 2.0h. However, the treatment with $1.5 \mathrm{~h}$ of $\mathrm{S}$ and $2.5 \mathrm{~h}$ of $\mathrm{D}$ showed the lower soil clay content. The differences 
Table 1 - Average, medium, minimum and maximum values and coefficient of variation (CV) of soil clay content in fifty soils from Rondônia State, determined by the method described in TEDESCO et al. (1995) under different periods of shaking (S) and decantation (D), and clay content determined by pipette method EMBRAPA (1997).

\begin{tabular}{|c|c|c|c|c|c|}
\hline \multirow{2}{*}{ Treatment } & Average $^{1}$ & Medium & Minimum & Maximum & \multirow{2}{*}{$\begin{array}{c}\mathrm{CV} \\
\end{array}$} \\
\hline & \multicolumn{4}{|c|}{ - } & \\
\hline $\mathrm{S}=1.5 \mathrm{~h}$ and $\mathrm{D}=2.5 \mathrm{~h}$ & $235 \mathrm{~d}$ & 225 & 35 & 550 & 7.4 \\
\hline $\mathrm{S}=2.0 \mathrm{~h}$ and $\mathrm{D}=2.5 \mathrm{~h}$ & $250 \mathrm{c}$ & 235 & 95 & 600 & 8.8 \\
\hline $\mathrm{S}=2.5 \mathrm{~h}$ and $\mathrm{D}=2.5 \mathrm{~h}$ & $251 \mathrm{c}$ & 247 & 25 & 585 & 9.1 \\
\hline $\mathrm{S}=2.0 \mathrm{~h}$ and $\mathrm{D}=1.5 \mathrm{~h}$ & $265 \mathrm{~b}$ & 240 & 65 & 610 & 8.5 \\
\hline $\mathrm{S}=2.0 \mathrm{~h}$ and $\mathrm{D}=2.0 \mathrm{~h}$ & $249 c$ & 235 & 25 & 585 & 10.5 \\
\hline Pipette & $285 \mathrm{a}$ & 271 & 22 & 702 & 5.1 \\
\hline
\end{tabular}

${ }^{1}$ Averages followed with distinct letters differ statistically $(\mathrm{P}<0.01)$ using the duplicate from the laboratory analysis. CV general: $9.5 \%$.

could be due the association of shorter period of shaking, which determine lesser mechanical dispersion, and larger period of decantation, which determine greater sedimentation of soil particles. In addition, the shaking through an orbital shaker with a sphere-glass to improve the soil detachment, contrasted with the methodology of shaking carried out with stirrer equipment in the EMBRAPA(1997) method.

In average, the range on both shaking and decantation periods did not differ regarding soil clay texture classes. The shaking period is important to mechanically detach and disperses the soil particles, and the lower shaking period was efficient. The reasons for this behavior was probably due to the fact of soils in Rondônia, and also in Brazil, are composed mainly of 1:1 clay type and iron and aluminum oxides, which have low activity. Moreover, they have low organic matter content, that is an important soil constituent that promote soil aggregation.

The decantation of weighed and larger soil particles, as both silt and sand, is faster than clay, which remains longer period in the suspension. The decantation velocity or particle sedimentation depends also upon the water temperature, and decantation increases with the laboratory environment temperature (EMBRAPA, 1997; TEDESCO et al., 1995). As the air temperature did not vary throughout the year in this region (INMET, 2008), the water presented low variation of temperature during this study.

The average, medium, minimum and maximum clay content distribution in soils used in this study is plotted in table 1 . The coefficient of variation was considerate low for soil clay content in the analyses of routine laboratory. The pipette method can measure more soil clay content than the alternative methods tested. However, some modifications tested were closely related with the standard method with high correlation degree. Maybe a further study could evaluate the impact of these differences on nutrient recommendations to crops, mainly P. The high correlation between modified (TEDESCO et al., 1995) and EMBRAPA (1997) methods indicated that the modified methods was efficient to estimate the soil clay content in Rondônia soils with reasonable precision (Figure 1).

TEDESCO et al. (1995) describes the methodology with shaking period of $2.0 \mathrm{~h}$ and decantation period of $2.5 \mathrm{~h}$ for evaluation of soil clay content for Southern Brazilian soils. However, the treatment with $\mathrm{S}$ of $2.0 \mathrm{~h}$ and $\mathrm{D}$ of $1.5 \mathrm{~h}$, used in this research, showed high correlation with the EMBRAPA (1997) method. The total consumption time was 3.5h, reducing $1.0 \mathrm{~h}$ in the analysis, improving the efficiency, reducing hand labor and relative costs, and moreover it can be held in a part-time day.

It was concluded that the treatment with association of $2.0 \mathrm{~h}$ of shaking and $1.5 \mathrm{~h}$ of decantation is the most suitable combination to day-to-day use for routine analysis of the soil clay content. The method showed fast and feasible execution in the routine soil testing laboratory of Rondônia State, with efficient precision. 

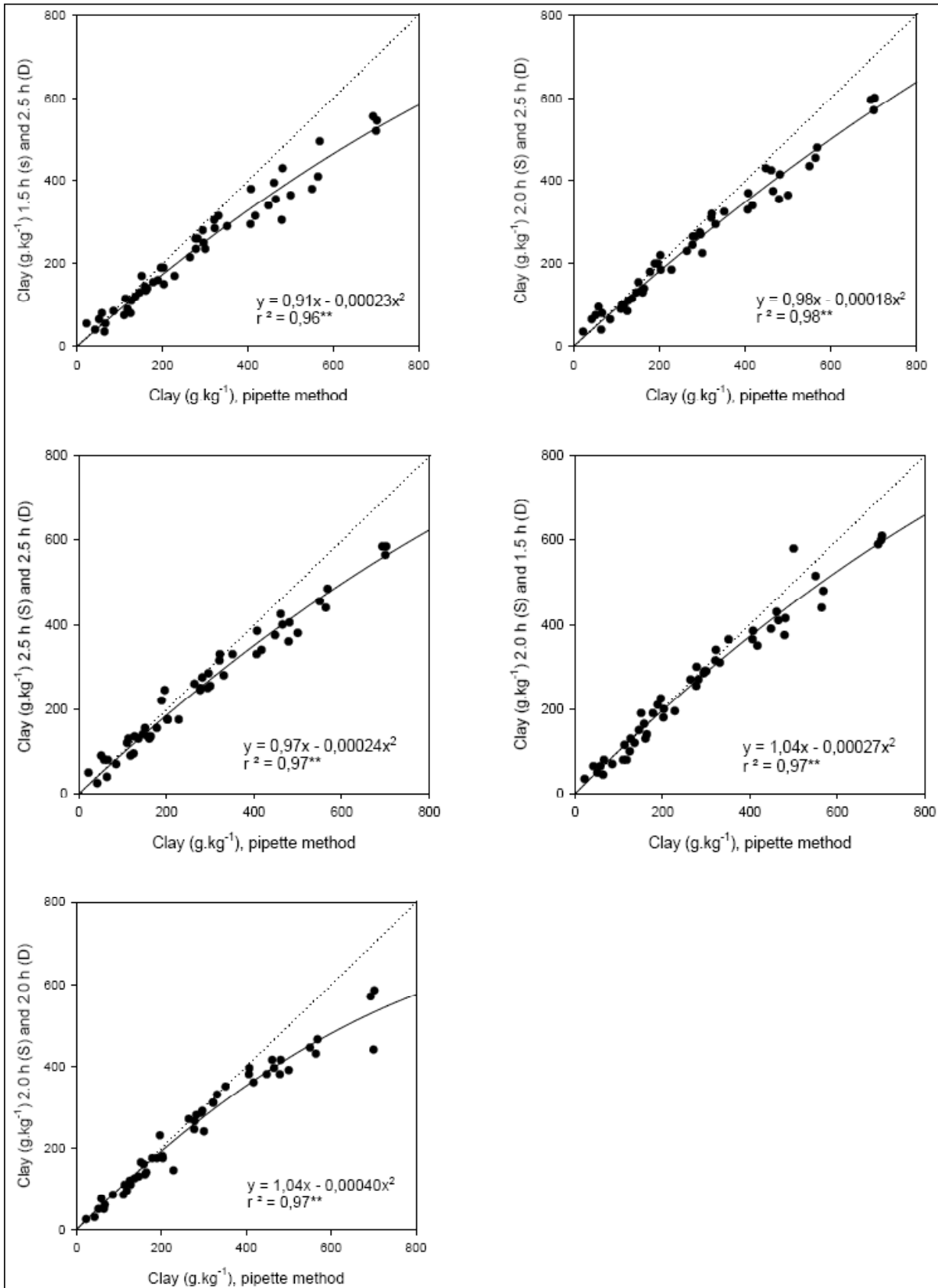

Figure 1 - Correlation between clay content determine with the pipette method (EMBRAPA, 1997) and with association of three shaking (S) and two decantation (D) periods using the method described in TEDESCO et al. (1995). ** Significant $\mathrm{P}<0.01$.

\section{REFERENCES}

COMISSÃO DE FERTILIDADE DO SOLO DO ESTADO DE MG - CFSEMG. Recomendação para o uso de corretivos e fertilizantes em Minas Gerais. 5 aproximação. Viçosa, 1999. $359 \mathrm{p}$

COMISSÃO DE FERTILIDADE DO SOLO RS/SC - CFSRS/SC. Manual de adubação e calagem para solo do Rio Grande do Sul e de Santa Catarina. 10.ed. Porto Alegre, 2004. 400p.
CUBILLA, M.M. et al. Calibração visando à fertilização com fósforo para as principais culturas de grãos sob sistema plantio direto no Paraguai. Revista Brasileira de Ciência do Solo, v.31, p.1463-1474, 2007. Available from: <http://www.scielo.br/ scielo.php? script $=\mathrm{sci}_{-}$art text \& pid=S $0100-$ 06832007000600023\&lng=en\&nrm=iso>. Accessed: 29 Apr. 2011. doi: 10.1590/S0100-06832007000600023.

EMPRESA BRASILEIRA DE PESQUISA AGROPECUÁRIA EMBRAPA. Centro Nacional de Pesquisa Solos. Manual de métodos de análise de solo. 2.ed. Rio de Janeiro, 1997. 212p. 
HILLEL, D. Introduction to environmental soil physics. New York: Academic, 2003. 392p.

INSTITUTO NACIONAL DE METEOROLOGIA - INMET. Mapas do boletim agroclimatológico. Available from: <http://www.inmet.gov.br〉. Accessed: 05 nov. 2008.

REICHERT, J.M. et al. Reference bulk density and critical degreeof-compactness for no-till crop production in subtropical highly weathered soils. Soil \& Tillage Research, v.102, p.242-254, 2009. Available from: <http://www.sciencedirect.com/ science?_ob=ArticleURL\&_udi=B 6 T C 6-4 T C 8J0P$1 \& \_$user $=10$ \&_rdoc $=1 \& \_$fmt $=$\&_orig $=$search $\& \_s o r t=d \& \_d o c a n c$ hor $=\&$ view $=c \&$ \& searchStrId=952824364\&_rerunOrigin $=$ google $\&$ _acct $=C 000050221$ \&_version $=1 \&$ \&urlVersion $=0$ \&_userid $=10 \& m d 5=$ 7d9806d993f1d455167129ff0ad90d9f>. Accessed: 29 Apr. 2011. doi:10.1016/j.still.2008.07.002.
SANCHES, P.A.; UEHARA, G. Management consideration for acid soil with high phosphorus fixation capacity. In: KHASAWNEH, F.R. et al. The role of phosphorus in agriculture. Madison: SSSA, 1980. p.471-514.

SCHLINDWEIN, J.A.; GIANELLO, C. Calibração de métodos de determinação de fósforo em solos cultivados sob sistema plantio direto. Revista Brasileira de Ciência do Solo, v.32, p.2037-2049, 2008. Available from: <http://www.scielo.br/ scielo.php ? s cript = sci_arttext \& pid=S $0100-$ $06832008000500025 \& \operatorname{lng}=e n \& n r m=i s o>$. Accessed: 29 Apr. 2011. doi: 10.1590/S0100-06832008000500025.

SOUZA, D.M.G.; LOBATO, E. (Ed.). Cerrado: correção do solo e adubação. Planaltina, DF: EMBRAPA Cerrados, 2002. 416p.

TEDESCO, M.J. et al. Análise de solo, plantas e outros materiais. 2.ed. Porto Alegre, UFRGS, 1995. 28p. (Boletim Técnico, 5). 